\title{
Impacts of the invasive grass Spartina anglica on benthic macrofaunal assemblages in a temperate Australian saltmarsh
}

\author{
Justin Cutajar, Jeff Shimeta*, Dayanthi Nugegoda \\ School of Applied Sciences, RMIT University, Melbourne, Victoria 3083, Australia
}

\begin{abstract}
Reported impacts of the invasive saltmarsh grass Spartina anglica on benthic macrofaunal assemblages around the world vary considerably, and there is little understanding of the reasons for this variation. We compared macrofaunal assemblages and sediment characteristics among patches of $S$. anglica and adjacent uninvaded habitats (bare mudflat and native saltmarsh) in southeastern Australia. Invaded patches showed reduced species richness (by $50 \%$ ) and diversity compared to both uninvaded habitats. Macrofaunal abundance in S. anglica patches was also lower than in native marsh (by $60 \%$ ), but not different from mudflat. There were no differences in biomass among habitats. Ordination clearly separated the species assemblage of invaded patches from uninvaded habitats, suggesting a unique community in the Spartina habitat. Molluscs and crustaceans were the most depleted in S. anglica patches, while the polychaete Nephtys australiensis was enhanced. Infauna and epifauna were both depleted in $S$. anglica, although the mechanisms for these impacts should differ. Burrowing by infauna in $S$. anglica patches was likely impeded by dense roots and rhizomes, because the below-ground plant biomass was $72 \%$ greater than in native saltmarsh. Epifauna were likely depleted in $S$. anglica patches due to shadinginduced inhibition of microphytobenthos growth, consistent with measured reductions of porewater salinity and increased mud content. Salinity and mud content were the sediment parameters that correlated most strongly with macrofaunal assemblage composition. These results, combined with a synthesis of published $S$. anglica impacts, suggest predictions of when $S$. anglica facilitates or inhibits macrofauna, considering infauna and epifauna separately.
\end{abstract}

KEY WORDS: Spartina anglica $\cdot$ Invasive species · Cordgrass · Macrofauna $\cdot$ Saltmarsh $\cdot$ Estuary · Australia

Resale or republication not permitted without written consent of the publisher

\section{INTRODUCTION}

Saltmarshes are recognized globally as ecosystems of significant ecological value that are under increasing threat (Adam 2002). Their importance extends beyond their boundaries, as plant material can be flushed into neighbouring waters, providing input for marine food webs, including those that contribute to aquaculture. Human impact has destroyed $>65 \%$ of these habitats over the last $300 \mathrm{yr}$, thereby reducing nursery habitats and sinks for nutrients and sediment
(Lotze et al. 2006). Invasive species are recognized as the single greatest threat to the biodiversity of saltmarshes and other coastal habitats around the world (Rönnbäck et al. 2007). The introduction of exotic species (deliberately or unintentionally), along with the increase of human disturbance to ecosystems, has facilitated a significant increase in biological invasions (Hobbs 2000).

Spartina species are temperate, intertidal saltmarsh grasses that are present as natives and nonnatives in Europe, North America, Asia, and Aus- 
tralasia (Ranwell 1964, Chung 1983, Groenendijk 1986, Kriwoken \& Hedge 2000). They can invade unvegetated sediment flats as well as saltmarshes, seagrass beds, mangroves, and cobble beds (Bridgewater 1975, Dethier \& Hacker 2005). By forming expansive monospecific swards with dense roots and rhizomes, invasive Spartina spp. are potent ecosystem engineers that severely impact native systems, e.g. by enhancing sediment accretion and stabilizing sediment against erosion (Blood 1995, Mudd et al. 2010), altering water flow (Bouma et al. 2005), and changing sediment characteristics such as grain size distribution (Whitlatch 1981, Edgar \& Shaw 1993), pH and salinity (Chung 1990), water content (Cottet et al. 2007), oxygen levels (da Cunha Lana \& Guiss 1991), organic matter (Peralta et al. 2008), and the biomass of subsurface root and rhizome material (Brusati \& Grosholz 2006, Neves et al. 2010).

These habitat-engineering effects can lead to changes in faunal communities such as displacement of species, colonization by new species, and associated changes in species richness and diversity (Neira et al. 2005, 2007, Zhou et al. 2009, Wang et al. 2010). Alteration of intertidal habitat and negative impacts on sediment invertebrate assemblages are of particular concern because these features of estuarine and saltmarsh ecosystems provide shelter and food for foraging birds, fishes, and economically important invertebrates (Bertness 1984, Simpson 1996, Hobbs 2000). There is some indication that Spartina invasion can alter trophic interactions; e.g. Levin et al. (2006) identified a trophic shift favoring polychaetes and oligochaetes (which consume Spartina detritus) over bivalves and amphipods that rely on microphytobenthos. Such a shift could cause loss of support for higher trophic levels such as fishes and migratory birds that feed on bivalves and amphipods (Levin et al. 2006).

Understanding and predicting the ecological impacts of Spartina spp. has been problematical because of contrasting findings within and between species that have been studied at various locations, especially regarding impacts on sediment macrofauna. Impacts of Spartina colonization have ranged from reduced macrofaunal density and species richness to enhanced density, richness, and biomass, or no impact compared to unvegetated sediment or areas of native vegetation (e.g. da Cunha Lana \& Guiss 1991, Neira et al. 2005, Chen et al. 2009, Wang et al. 2010). Neira et al. (2005) reviewed published impacts, emphasizing studies on $S$. alterniflora, $S$. foliosa, and the hybrid $S$. foliosa $\times S$. alterniflora. They came to the generalization that where it is native and has grown to a mature state, colonized areas of Spartina spp. (especially S. alterniflora) enhance macrofaunal populations compared to unvegetated sediment, whereas in areas where it is nonnative it depletes the macrofauna - although there are exceptions (Neira et al. 2005, Wang et al. 2010).

Mechanisms underlying variable impacts are not well understood, but they appear related to factors such as the species of Spartina, age and extent of invasion, susceptibility of the habitat being overrun, extent and structure of above-ground and belowground plant biomass, and hydrodynamic regime (Neira et al. 2005, 2006, 2007, Brusati \& Grosholz 2006, Hacker \& Dethier 2006). A number of mechanisms by which saltmarsh vegetation and habitat factors influence invertebrates have been studied (e.g. plant structure, food resources from plants, elevation, grain size, salinity, oxygen, and organic matter; reviewed by Levin \& Talley 2000), yet a clear predictive understanding of the conditions under which Spartina spp. produce the various documented impacts on macrofauna has not emerged.

Spartina anglica is the most widespread invasive Spartina species, occurring in mainland Europe, the UK, North America, China, New Zealand, and Australia (Lee \& Partridge 1983, Jackson et al. 1985, Chung 1990, Kriwoken \& Hedge 2000, Lowe et al. 2000, Nehring \& Hesse 2008). It is of recent origin, arising in England by chromosome doubling from the sterile hybrid $S$. maritima $\times$ alterniflora (Thompson 1991). It is a strong competitor, with exceptional growth rates and tolerance to a wide range of temperature, salinity, and inundation conditions (Thompson 1991, Nehring \& Hesse 2008). For these reasons it should not be assumed to have the same impacts as other Spartina species.

Despite great concern over Spartina anglica as an invasive species, its impacts on macrofauna have been studied less than those of other Spartina species, and the limited studies have shown variable effects. Compared to unvegetated sediment, areas colonized by $S$. anglica showed reduced macrofaunal abundance and/or diversity in the UK (Jackson 1985, Frid \& James 1989) and the Danish Wadden Sea (Tang \& Kristensen 2010), but increased abundance and species richness in Australia (Hedge \& Kriwoken 2000). Other studies found variable or little impact in the UK (Millard \& Evans 1984, Jackson et al. 1985), on the Atlantic coast of France (Cottet et al. 2007), and in the Netherlands (Bouma et al. 2009). Not all of these studies, however, compared habitats sampled simultaneously; some compared the macrofauna in $S$. anglica infestations to historical data from unin- 
vaded sites (Jackson et al. 1985, Frid \& James 1989), therefore not controlling for any shifts of the communities over time. Even fewer studies have made comparisons to areas of native vegetation (saltmarsh plants or seagrasses), and again the differences in macrofaunal populations were variable (Cottet et al. 2007, Bouma et al. 2009) or insignificant (Hedge \& Kriwoken 2000). Because of its origin, S. anglica is exotic everywhere it colonizes and therefore it does not fit Neira et al.'s (2005) generalization that nonnative Spartina spp. typically have negative impacts on macrofauna. Factors determining whether $S$. anglica's impacts on macrofauna are positive, negative, or neutral are unknown.

Spartina anglica was introduced deliberately to Australia in the late 1920s (Boston 1981). It covers an estimated 600 and 300 ha in the states of Victoria and Tasmania, respectively (Wells 1995, Weiss \& Iaconis 2002). There is concern that rising sea levels associated with climate change may accelerate the spread of $S$. anglica inland, possibly faster than native marsh will shift (Saintilan 2009). Extensive control programs are in place in both states where $S$. anglica occurs, spraying infested habitats with herbicides. Despite these concerns, there are few data on the impacts of invasion on macrofaunal assemblages in Australia. The only previously published study was in Tasmania and found that macrofaunal populations in S. anglica patches were enhanced compared to mudflats, suggesting that invasion converts mudflat into the equivalent of native saltmarsh in terms of macrofaunal abundance and species richness (Hedge \& Kriwoken 2000).

To better understand the impacts of Spartina anglica on macrofaunal invertebrates, we conducted simultaneous sampling of invaded patches and adjacent mudflat and native saltmarsh in Victoria, Australia. We measured a variety of habitat parameters in an attempt to identify mechanisms accounting for any effects on the macrofauna. Our results, together with a detailed review of previous papers on $S$. anglica, lead to hypotheses concerning factors that determine whether impacts of $S$. anglica on macrofauna are beneficial or detrimental.

\section{MATERIALS AND METHODS}

\section{Sampling}

Anderson Inlet, Victoria, is a creek-fed estuary in the southeast of Australia, $12.5 \mathrm{~km}$ long $\times 2.7 \mathrm{~km}$ wide, with an opening to the coast of $2.1 \mathrm{~km}$ width
(Fig. 1). It has an assortment of intertidal mudflat, sandflat, higher-intertidal native saltmarsh, lowerintertidal mangroves Avicennia marina, and areas invaded by Spartina anglica, the latter of which total 196 ha (Boon et al. 2011). We collected samples in the transition zone between unvegetated mudflat and native saltmarsh dominated by Sarcocornia quinqueflora. This area has been infested with $S$. anglica for the past 8 yr (Parks Victoria pers. comm.), occurring in patches from 1 to $2 \mathrm{~m}^{2}$. The site is bordered by farms, a canal, and a levee and is therefore relatively inaccessible. The inlet is predominantly used for recreational fishing.

We sampled in 5 replicate blocks of approx. $400 \mathrm{~m}^{2}$ that each contained areas of unvegetated mudflat, native saltmarsh (predominantly Sarcocornia quinqueflora), and discrete Spartina anglica patches in the upper-mid-intertidal. Each block was separated from the others by $\geq 100 \mathrm{~m}$. In each block, we sampled from 3 uniform patches (1 each of mudflat, native marsh, and $S$. anglica) at the same elevation. Over a $1 \mathrm{wk}$ period in late May to early June 2009 (austral autumn), we collected triplicate sediment cores (15 cm diameter $\times 10 \mathrm{~cm}$ deep) for macrofauna from haphazard locations ( $\geq 50 \mathrm{~cm}$ inside the patch boundary) in each patch of each block. Adjacent to each of these macrofaunal cores we collected 2 cores $(3 \mathrm{~cm}$ diameter $\times 10 \mathrm{~cm}$ deep) for measuring sediment parameters.

Macrofauna were separated from cored sediment on a $500 \mu \mathrm{m}$ mesh sieve, preserved in $10 \%$ buffered formalin, and transferred after $7 \mathrm{~d}$ to $70 \%$ ethanol. Specimens were identified to the lowest possible taxonomic level under a dissecting microscope. They were dried at $75^{\circ} \mathrm{C}$ for measuring dry weight, after which biomass was measured as the dried mass lost on combustion at $500^{\circ} \mathrm{C}$ for $4 \mathrm{~h}$. From each set of

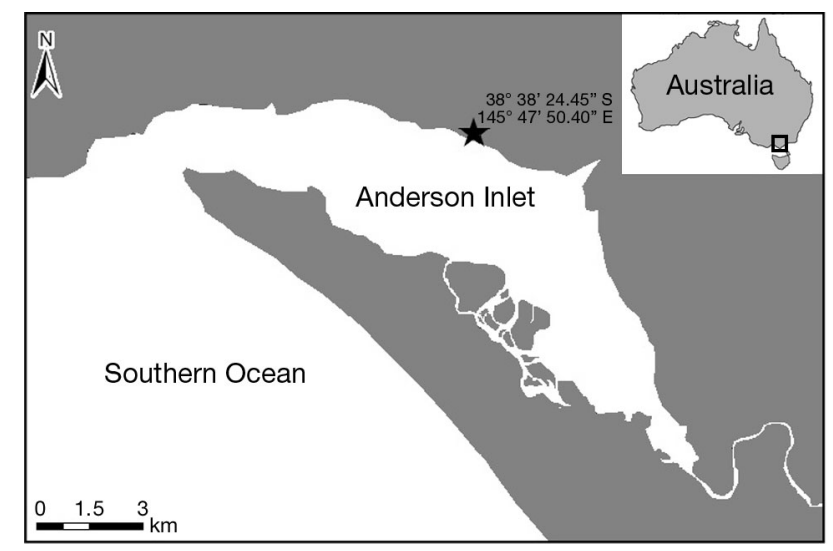

Fig. 1. Sampling site, Anderson Inlet, Australia 
6 replicate cores per patch collected for sediment parameters, 4 were chosen randomly to measure moisture content by oven-drying at $90^{\circ} \mathrm{C}$ for $2 \mathrm{~d}$. Three of these samples were then chosen randomly to measure organic matter content as dry mass lost on combustion at $500^{\circ} \mathrm{C}$ for $4 \mathrm{~h}$. The fourth sample was rehydrated and wet-sieved to determine the particle-size distribution, measured as the percent mass in each size class after final drying. The remaining 2 cores from each set of 6 replicates were used to measure salinity and $\mathrm{pH}$ in porewater separated by centrifugation. For each type of measure (biotic and abiotic), data from replicate cores within each patch were pooled.

Additional data on below-ground plant biomass were collected at the same locations in the summer of 2011. Cores of $15 \mathrm{~cm}$ diameter $\times 10 \mathrm{~cm}$ deep were taken in patches of Spartina anglica and patches of native marsh. Below-ground plant material retained on a $500 \mu \mathrm{m}$ mesh sieve was separated from animals and washed to remove sediment, then dried and weighed.

\section{Statistical analyses}

Several assemblage indices were calculated to compare macrobenthic communities among the 3 habitats. These included species richness (number of species), abundance (number of individuals), and Shannon-Wiener species diversity ( $H^{\prime} ;$ Pielou 1966). The indices were calculated for total macrofauna as well as for major taxonomic groups (molluscs, annelids, and crustaceans).

Differences in assemblage indices and environmental variables among habitats were tested with a linear mixed-model ANOVA on Systat 13, with habitat as a fixed factor and sampling blocks as a random factor. Significant results $(\alpha=0.05)$ were followed by Tukey pairwise comparisons. Below-ground plant biomass, however, was tested with a paired $t$-test because these data were only collected for the 2 types of vegetated habitat. Before testing, all data were $\log (x+1)$ transformed to improve normality and reduce heteroscedasticity.

Differences in $\log (x+1)$-transformed species abundances and presence/absence were tested using non-parametric multidimensional scaling (MDS), based on Bray-Curtis dissimilarity matrices. Pairwise comparisons for differences in macrofaunal assemblages between habitats were made using the analysis of similarity (ANOSIM) test. Similarity percentage (SIMPER) analyses were used to determine the percent of dissimilarity between habitats.
BIOENV analyses were run on macrofaunal abundances and sediment data (both $\log (x+1)$ transformed) to determine which sediment parameters best explained the distribution of the macrofaunal assemblages. Below-ground plant biomass was excluded from the analysis because it was not collected simultaneously with the other data. BIOENV analyses provided Spearman's ranked correlation coefficients for the sediment parameters, suggesting their level of influence on the macrofaunal assemblages. However, this analysis is strictly observational, and does not necessarily indicate a causal relationship. The MDS, ANOSIM, SIMPER, and BIOENV analyses were run in Primer 6.

\section{RESULTS}

A total of 20 benthic macrofaunal species were identified from the 3 habitats (Table 1). Patches of native saltmarsh yielded the most species (17) and most individuals (414), consisting predominantly of the detritivorous snails Tatea huonesis and Ophi-

Table 1. Total numbers of macrofauna (individuals) according to habitat in all samples combined, and species richness (number of species, bottom row). E: epifaunal; I: infaunal

\begin{tabular}{|c|c|c|c|}
\hline & $\begin{array}{c}\text { Native } \\
\text { saltmarsh }\end{array}$ & $\begin{array}{c}\text { Spartina } \\
\text { anglica }\end{array}$ & $\begin{array}{l}\text { Mud- } \\
\text { flat }\end{array}$ \\
\hline \multicolumn{4}{|l|}{ Mollusca } \\
\hline Salinator fragilis $(\mathrm{E})$ & 5 & 0 & 0 \\
\hline Salinator solida (E) & 50 & 50 & 69 \\
\hline Eulima sp. (E) & 7 & 0 & 0 \\
\hline Tatea huonensis $(\mathrm{E})$ & 120 & 28 & 28 \\
\hline Ophicardelus ornatus (E) & 89 & 8 & 19 \\
\hline Ophicardelus quoyi (E) & 63 & 24 & 4 \\
\hline Tellina deltoidalis (I) & 6 & 0 & 5 \\
\hline Mysella donaciformis (I) & 4 & 4 & 5 \\
\hline Assiminea buccinoides (E) & 6 & 0 & 8 \\
\hline \multicolumn{4}{|l|}{ Crustacea } \\
\hline Heloecius cordiformis (I) & 13 & 0 & 56 \\
\hline Helograpsus haswellianus (I) & 19 & 18 & 14 \\
\hline Parasesarma erythrodactyla (I) & 6 & 0 & 6 \\
\hline Paragrapsus gaimardii (E) & 5 & 0 & 3 \\
\hline Paragrapsus laevis (E/I) & 0 & 12 & 0 \\
\hline Macrophthalmus latifrons (I) & 5 & 0 & 22 \\
\hline Mictyris platycheles (I) & 0 & 0 & 4 \\
\hline Allorchestes compressa (E) & 8 & 2 & 21 \\
\hline \multicolumn{4}{|l|}{ Annelida } \\
\hline Capitella capitata (I) & 3 & 0 & 0 \\
\hline Nephtys australiensis (I) & 5 & 22 & 3 \\
\hline Scoloplos cylindrifer (I) & 0 & 0 & 4 \\
\hline Species richness & 17 & 9 & 16 \\
\hline
\end{tabular}


cardelus ornatus. Mudflat patches yielded slightly fewer species (16) and individuals (271), dominated by the detritivorous snail Salinator solida and the deposit-feeding semaphore crab Heloecius cordiformis. Patches of Spartina anglica yielded the fewest species (9) and the fewest individuals (168), dominated by Salinator solida.

Populations that were most depleted in the Spartina anglica patches were molluscs and crustaceans (the snails Ophicardelus ornatus and Assiminea buccinoides; the bivalve Tellina deltoidalis; the crabs Heloecius cordiformis, Parasesarma erythrodactyla, Paragrapsus gaimardii, and Macrophthalmus latifrons; and the amphipod Allorchestes compressa; Table 1). Eleven species that were found in at least one of the uninvaded habitats were absent in our samples from $S$. anglica patches. There was no evident difference between the effects on infaunal and epifaunal taxa. Reduced (or absent) populations in S. anglica compared to one or both uninvaded habitats occurred for 7 of the 10 infaunal species and 9 of the 10 epifaunal species (Table 1). The only species that were enhanced in invaded patches were the shore crab Paragrapsus laevis and the polychaete Nephtys australiensis.

Mean species richness of total macrofauna differed significantly among habitats (Fig. 2). Richness was ca. $50 \%$ lower in the Spartina anglica patches compared to the native saltmarsh and mudflat habitats, while there was no difference between native marsh and mudflat. In particular, S. anglica patches had significantly reduced richness of molluscs and crustaceans compared to native saltmarsh, and the crustaceans were also less rich than in the mudflat (Table 2).

Mean species diversity of total macrofauna showed the same pattern as species richness, being lowest in the Spartina anglica patches, while the native saltmarsh and mudflat did not differ from each other (Fig. 2). $S$. anglica patches had lower diversity of molluscs and crustaceans com- pared to native saltmarsh, and the crustaceans were also less diverse than in the mudflat (Table 2).

Mean abundance of total macrofauna differed significantly among habitats (Fig. 2). Abundance in Spartina anglica patches was $40 \%$ of that in native saltmarsh, but it did not differ from mudflat. Molluscs were less abundant in $S$. anglica than in native
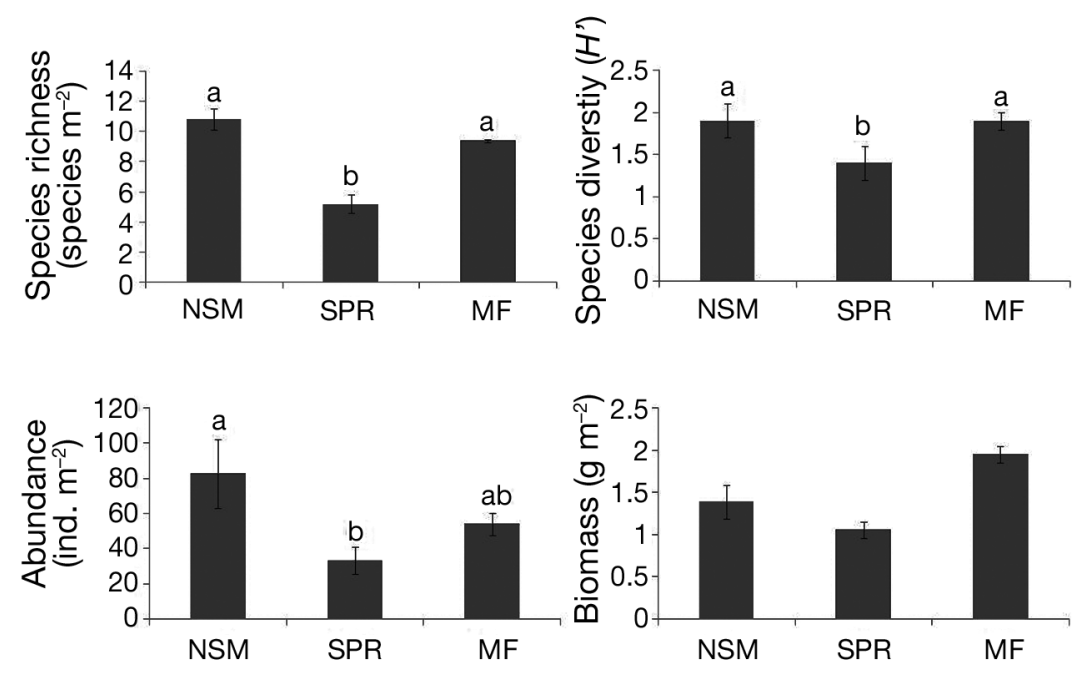

Fig. 2. Mean $( \pm \mathrm{SE})$ species richness, diversity, abundance and biomass of total macrofauna averaged among sampling blocks for each habitat type; $\mathrm{p}=0.001,0.020,0.026$ and 0.206 , respectively (linear mixed-model ANOVA). In each panel, means with different letters are significantly different $(\mathrm{p}<0.05$ in pairwise tests). NSM: native saltmarsh; SPR: Spartina anglica; MF: mudflat

Table 2. Mean $( \pm \mathrm{SE})$ species richness, diversity, abundance, and biomass for taxonomic groups of macrofauna averaged among sampling blocks for each habitat type ( $p$-values from linear mixed-model ANOVA). Means with different superscript letters in the same row are significantly different $(p<0.05$ in pairwise tests)

\begin{tabular}{|c|c|c|c|c|}
\hline & Native saltmarsh & Spartina anglica & Mudflat & $\mathrm{p}$ \\
\hline \multicolumn{5}{|c|}{ Species richness (species $\mathrm{m}^{-2}$ ) } \\
\hline Mollusca & $5.8 \pm 0.55^{\mathrm{a}}$ & $3.0 \pm 0.55^{\mathrm{b}}$ & $4.9 \pm 0.32^{\mathrm{a}, \mathrm{b}}$ & 0.045 \\
\hline Annelida & $0.8 \pm 0.59$ & $0.6 \pm 0.55$ & $0.8 \pm 0.32$ & 0.860 \\
\hline Crustacea & $3.8 \pm 0.34^{\mathrm{a}}$ & $1.6 \pm 0.57^{\mathrm{b}}$ & $4.8 \pm 0.49^{\mathrm{a}}$ & 0.010 \\
\hline \multicolumn{5}{|c|}{ Species diversity $\left(H^{\prime}\right)$} \\
\hline Mollusca & $1.4 \pm 0.13^{\mathrm{a}}$ & $0.7 \pm 0.20^{\mathrm{b}}$ & $1.0 \pm 0.09^{a, b}$ & 0.034 \\
\hline Annelida & $0.6 \pm 0.13$ & $0.0 \pm 0.00$ & $0.0 \pm 0.00$ & 0.410 \\
\hline Crustacea & $1.3 \pm 0.09^{\mathrm{a}}$ & $0.5 \pm 0.25^{\mathrm{b}}$ & $1.2 \pm 0.10^{\mathrm{a}}$ & 0.009 \\
\hline \multicolumn{5}{|c|}{ Abundance (ind. $\mathrm{m}^{-2}$ ) } \\
\hline Mollusca & $70.0 \pm 19.61^{a}$ & $22.8 \pm 7.41^{\mathrm{b}}$ & $27.4 \pm 4.76^{\mathrm{a}, \mathrm{b}}$ & 0.033 \\
\hline Annelida & $1.6 \pm 0.81$ & $4.4 \pm 2.01$ & $1.4 \pm 0.04$ & 0.609 \\
\hline Crustacea & $11.2 \pm 1.98^{\mathrm{a}, \mathrm{b}}$ & $6.4 \pm 1.69^{\mathrm{a}}$ & $24.8 \pm 1.97^{\mathrm{b}}$ & 0.019 \\
\hline \multicolumn{5}{|c|}{ Biomass $\left(\mathrm{g} \mathrm{m}^{-2}\right)$} \\
\hline Mollusca & $0.7 \pm 0.10$ & $0.4 \pm 0.07$ & $0.8 \pm 0.12$ & 0.105 \\
\hline Annelida & $0.013 \pm 0.008$ & $0.047 \pm 0.021$ & $0.011 \pm 0.005$ & 0.075 \\
\hline Crustacea & $0.7 \pm 0.10$ & $0.6 \pm 0.15$ & $1.13 \pm 0.19$ & 0.079 \\
\hline
\end{tabular}


marsh, and crustaceans were less abundant in $S$. anglica than in mudflat (Table 2). There were no significant differences in macrofaunal biomass among the habitats, either for total macrofauna or for taxonomic groups (Fig. 2, Table 2).

MDS of the macrofaunal assemblages based on species presence/absence clearly separated Spartina anglica assemblages from the native saltmarsh and mudflat communities (Fig. 3). The native saltmarsh and mudflat sites had some overlap in the ordination space. ANOSIM and SIMPER tests found the greatest dissimilarities between the invaded patches and either the native saltmarsh or mudflat assemblages (dissimilarity of $51 \%$, ANOSIM R $=0.52, \mathrm{p}=0.008$; and dissimilarity of $57 \%, \mathrm{R}=0.58, \mathrm{p}=0.008$, respectively; Table 3). Native saltmarsh and mudflat assemblages were not significantly different (dissimilarity of only $33 \%$, ANOSIM R $=-0.02, \mathrm{p}=0.5$; Table 3 ). When the fauna were grouped into categories of molluscs, annelids, and crustaceans, the separations among habitats in ordination space were not as evident. Nonetheless, both molluscs and crustaceans in the invaded patches were most dissimilar from the native saltmarsh and mudflat habitats, being significantly different in most cases $(p<0.05$; Table 3 ). Annelid assemblages did not differ significantly among habitats ( $p>0.05$; Table 3$)$.

Ordination based on species abundance clearly separated all habitat assemblages from one another (combined taxa; Fig. 4), with all pairwise ANOSIM tests significant $(\mathrm{p}<0.05$; Table 4$)$. The mollusc assemblage was significantly different between Spartina anglica and native saltmarsh, while the

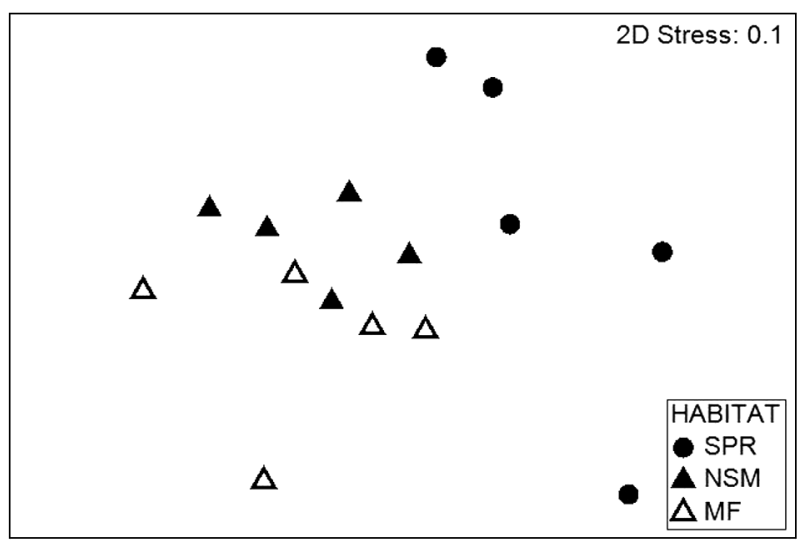

Fig. 3. MDS ordination of species presence/absence in replicate sampling blocks, based on the 20 macrofaunal species in Table 1. SPR: Spartina anglica; NSM: native saltmarsh; MF: mudflat
Table 3. Pairwise ANOSIM ( $R, p$ ) and SIMPER (dissimilarity $\%)$ comparisons of Bray-Curtis dissimilarities, based on presence/absence of species in the assemblages. SPR: Spartina anglica; NSM: native saltmarsh; MF: mudflat

\begin{tabular}{|lrcc|}
\hline Group & $\mathrm{R}$ & $\begin{array}{c}\text { Adjusted } \\
\text { p-value }\end{array}$ & $\begin{array}{c}\text { Dissimilarity } \\
\%\end{array}$ \\
\hline Mollusca & & & \\
SPR vs. NSM & 0.19 & 0.040 & 40.0 \\
SPR vs. MF & -0.01 & 0.484 & 40.5 \\
NSM vs. MF & 0.11 & 0.175 & 31.3 \\
Crustacea & & & \\
SPR vs. NSM & 0.60 & 0.008 & 69.1 \\
SPR vs. MF & 0.65 & 0.008 & 75.9 \\
NSM vs. MF & -0.05 & 0.595 & 26.4 \\
Annelida & & & \\
SPR vs. NSM & 0.00 & 0.587 & 76.9 \\
SPR vs. MF & 0.00 & 0.524 & 73.9 \\
NSM vs. MF & 0.04 & 0.460 & 85.5 \\
Combined taxa & & & \\
SPR vs. NSM & 0.52 & 0.008 & 51.1 \\
SPR vs. MF & 0.58 & 0.008 & 57.0 \\
NSM vs. MF & -0.02 & 0.500 & 33.3 \\
\hline
\end{tabular}

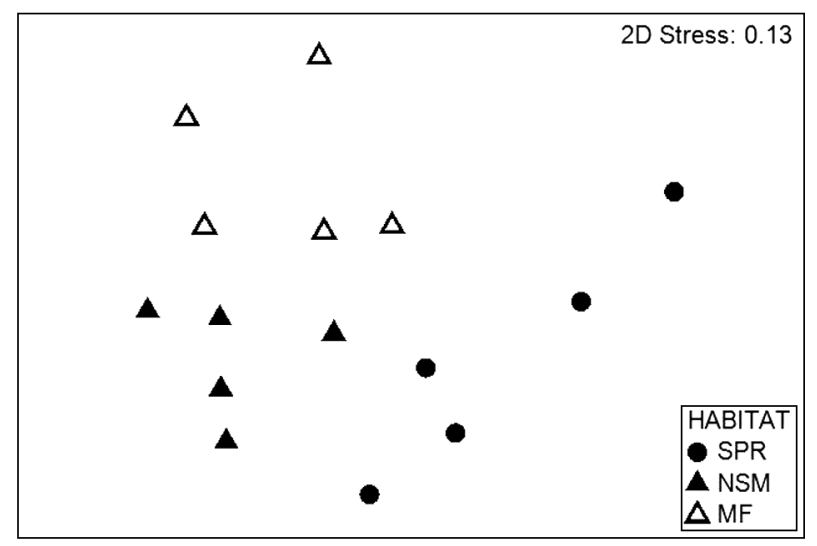

Fig. 4. MDS ordination of species abundance in replicate sampling blocks, based on the 20 macrofaunal species in Table 1. SPR: Spartina anglica; NSM: native saltmarsh; MF: mudflat

crustacean assemblage in $S$. anglica differed from both uninvaded habitats $(\mathrm{p}<0.05$; Table 4$)$. For molluscs, crustaceans, and annelids the assemblages in the 2 uninvaded habitats also differed ( $p<0.05$ for native saltmarsh vs. mudflat; Table 4).

The sediment in patches invaded by Spartina anglica had significantly greater mud content (ca. 2 -fold) and lower porewater salinity compared to native saltmarsh and mudflat patches (Table 5). The $\mathrm{pH}$ in $S$. anglica patches was lower than in mudflat, 
Table 4. Pairwise ANOSIM ( $\mathrm{R}, \mathrm{p})$ and SIMPER (dissimilarity $\%)$ comparisons of Bray-Curtis dissimilarities, based on abundances of species in the assemblages. SPR: Spartina anglica; NSM: native saltmarsh; MF: mudflat

\begin{tabular}{|lrcc|}
\hline Group & $\mathrm{R}$ & $\begin{array}{c}\text { Adjusted } \\
\text { p-value }\end{array}$ & $\begin{array}{c}\text { Dissimilarity } \\
\%\end{array}$ \\
\hline Mollusca & & & \\
SPR vs. NSM & 0.38 & 0.032 & 65.2 \\
SPR vs. MF & -0.13 & 0.825 & 55.0 \\
NSM vs. MF & 0.37 & 0.040 & 65.6 \\
Crustacea & & & \\
SPR vs. NSM & 0.43 & 0.008 & 70.8 \\
SPR vs. MF & 0.65 & 0.008 & 87.6 \\
NSM vs. MF & 0.62 & 0.016 & 62.1 \\
Annelida & & & \\
SPR vs. NSM & 0.01 & 0.365 & 86.4 \\
SPR vs. MF & 0.06 & 0.286 & 90.5 \\
NSM vs. MF & 0.05 & 0.016 & 91.4 \\
Combined taxa & & & \\
SPR vs. NSM & 0.44 & 0.024 & 67.1 \\
SPR vs. MF & 0.61 & 0.008 & 70.0 \\
NSM vs. MF & 0.62 & 0.008 & 65.4 \\
\hline
\end{tabular}

but similar to native saltmarsh. Below-ground plant biomass in the $S$. anglica patches was $72 \%$ greater than that in the native marsh patches. There were no significant differences in organic matter, moisture content, or median grain size.

The multivariate analysis BIOENV found that salinity and mud content were the sediment parameters that correlated most strongly with macrofaunal assemblage composition (Table 6). Below-ground plant biomass was not included in the analysis because those data were not collected simultaneously with the rest.

Table 5. Environmental parameters (mean \pm SE) averaged among sampling blocks for each habitat type; $p$-values are from linear mixed model ANOVA, except below-ground plant biomass from a paired $t$-test. Means with different superscript letters in the same row are significantly different $(p<0.05$ in pairwise tests). NA: not applicable

\begin{tabular}{|c|c|c|c|c|}
\hline & $\begin{array}{l}\text { Native } \\
\text { saltmarsh }\end{array}$ & $\begin{array}{l}\text { Spartina } \\
\text { anglica }\end{array}$ & Mudflat & $\mathrm{p}$ \\
\hline Organic matter (\%) & $17.6 \pm 2.2$ & $12.2 \pm 1.9$ & $13.3 \pm 2.3$ & 0.260 \\
\hline Moisture content $(\%)$ & $54.9 \pm 2.6$ & $48.1 \pm 2.4$ & $47.5 \pm 2.1$ & 0.368 \\
\hline Salinity $\left(\mathrm{g} \mathrm{kg}^{-1}\right)$ & $24.5 \pm 0.4^{\mathrm{a}}$ & $20.8 \pm 0.3^{b}$ & $25.0 \pm 0.4^{\mathrm{a}}$ & $<0.001$ \\
\hline $\mathrm{pH}$ & $7.2 \pm 0.4^{\mathrm{a}}$ & $7.2 \pm 0.3^{\mathrm{a}}$ & $7.7 \pm 0.1^{b}$ & $<0.001$ \\
\hline Median grain size $(\mu \mathrm{m})$ & $193.0 \pm 27.0$ & $228.5 \pm 11.7$ & $250.0 \pm 12.7$ & 0.096 \\
\hline Mud content $(\%,<63 \mu \mathrm{m})$ & $4.6 \pm 0.4^{\mathrm{a}}$ & $7.6 \pm 0.6^{\mathrm{b}}$ & $3.5 \pm 0.4^{\mathrm{a}}$ & $<0.001$ \\
\hline $\begin{array}{l}\text { Below-ground plant } \\
\text { biomass }\left(\mathrm{kg} \mathrm{m}^{-2}\right)\end{array}$ & $3.2 \pm 0.3^{\mathrm{a}}$ & $5.5 \pm 0.8^{b}$ & NA & 0.008 \\
\hline
\end{tabular}

Table 6. BIOENV ranking of correlations ( $\rho$-values) between sediment parameters and macrofaunal assemblage composition

\begin{tabular}{|llc|}
\hline Rank & $\begin{array}{c}\text { Environmental } \\
\text { variable }\end{array}$ & $\begin{array}{c}\text { Correlation } \\
\text { coefficient }\end{array}$ \\
\hline 1 & Salinity & 0.266 \\
2 & Mud content & 0.195 \\
3 & pH & 0.024 \\
4 & Median grain size & -0.041 \\
5 & Organic content & -0.056 \\
6 & Moisture content & -0.097 \\
\hline
\end{tabular}

\section{DISCUSSION}

\section{Mechanisms of Spartina anglica impact}

Patches of $S$. anglica had significant reductions of macrofaunal abundance (by as much as $60 \%$ ), species richness (by 50\%), and diversity compared to uninvaded habitat. Populations of infaunal and epifaunal species were both depleted in $S$. anglica, but they were likely affected by different mechanisms.

Infaunal species could have been depleted from Spartina anglica patches by inhibition of burrowing, as suggested by the greater below-ground biomass of roots and rhizomes compared to both the native marsh and mudflat. Although we measured plant biomass in the summer of a subsequent year after the macrofauna were collected in autumn, S. anglica and the dominant native marsh plant, Sarcocornia quinqueflora, are perennials, and their below-ground components should be relatively stable.

Among those species depleted from Spartina anglica patches, Heloecius cordiformis, Macrophthalmus latifrons, and Mictyris platycheles are side-burrowing crustaceans that descend at a shallow angle into the sediment (Ringold 1979, Brenchley 1982, Poore 2007), such that they would be blocked by the denser root systems of $S$. anglica compared to native marsh vegetation. van Wesenbeeck et al. (2007) and Bouma et al. (2009) also concluded that enhanced sediment compaction and fine-grained sediment abundance in $S$. anglica habitat hampered the burrowing ability of crustaceans and polychaetes. Likewise, Brusati \& Grosholz (2006) concluded that the dense below-ground structure of the invasive hybrid $S$. foliosa $\times$ alterniflora excludes infauna, and they further- 
more showed a threshold effect by finding that the less dense roots and rhizomes of native $S$. foliosa have no inhibitory effect. Our results are consistent with a similar threshold effect in that, compared to the mudflat, infauna were excluded from the below-ground structure of the $S$. anglica habitat, but not from the less dense native marsh habitat. In another Spartina species, Capehart \& Hackney (1989) found that burrowing by the clam Polymesoda caroliniana was inhibited by $S$. alterniflora roots and rhizomes more than by other marsh vegetation. As a different explanation for inhibition of infauna, Neira et al. (2006) showed that the canopy structure of the hybrid $S$. foliosa $\times$ alterniflora reduces flow and enhances deposition of fine sediment, leading to reduced oxygen levels in sediment. Our similar findings of enriched mud content in $S$. anglica patches compared to both native marsh and mudflat could likewise indicate exclusion of infauna by low oxygen levels.

Other authors have suggested or demonstrated an opposite effect, i.e. that the subsurface biomass of Spartina spp. can be favourable to infauna by increasing habitat heterogeneity and sediment oxygenation (da Cunha Lana \& Guiss 1991, 1992, Gribsholt \& Kristensen 2002, Brusati \& Grosholz 2006). Levin \& Talley (2000) reviewed various other positive and negative relationships between invertebrates and the biomass and density of Spartina spp. The only species we found to be notably enhanced in $S$. anglica patches were the burrowing predatory polychaete Nephtys australiensis and the shore crab Paragrapsus laevis (primarily epifaunal but can dig burrows). These species presumably benefit from the subsurface structuring effects more than they are inhibited by the roots and rhizomes-although the population of $P$. laevis might be more influenced by the above-ground habitat provided by $S$. anglica (see below). Hedge \& Kriwoken (2000) also found abundances of $N$. australiensis to be greater in patches of $S$. anglica compared to uninvaded habitats.

Epifaunal species at our site could have been depleted in Spartina anglica patches due to reduced microalgal food resources for grazers. Evidence for this effect is the reduced porewater salinity compared to both mudflat and native marsh, indicating a shading effect from $S$. anglica that reduces evaporation on the sediment and which could lower the productivity of microalgae. Salinity was also the physical factor most strongly correlated with our macrofaunal assemblage structure. Similarly, Hacker \& Dethier (2006) found reduced porewater salinity in S. anglica infestations compared to mudflat and native marsh in the United States. Also, Neira et al. (2005) found reduced salinity in areas of invasive $S$. foliosa $\times$ alterniflora compared to both unvegetated sediment and marsh dominated by Salicornia quinqueflora, a glasswort similar in structure to the Sarcocornia virginica at our site.

Consistent with our hypothesis, canopy size of Spartina spp. has been shown to be related to the amount of shading (Brusati \& Grosholz 2006) and microalgal production (Sullivan \& Currin 2000) at the sediment surface. da Cunha Lana \& Guiss (1992) even documented an inverse relationship between aerial biomass of $S$. alterniflora and epifaunal abundance, offering a similar explanation of reduced microalgal production caused by shading. Also, Levin et al. (2006) found that reduced biomass of surface-feeding infauna in $S$. foliosa $\times$ alterniflora habitat compared to unvegetated sediment corresponded to reduced sediment microalgal productivity. At our site, $S$. anglica has a much taller and denser canopy than the creeping glasswort Sarcocornia quinqueflora that dominates the native marsh (ca. 50 vs. $15 \mathrm{~cm}$, respectively), which suggests greater shading by $S$. anglica than by $S$. quinqueflora. The effects of a larger canopy are also seen in the increased mud content of the $S$. anglica sediment compared to the native marsh and mudflat (Table 5), caused by a baffling effect on the flow that enhances deposition of fine particles (Neira et al. 2006).

Other authors, though, have found enhanced populations of epifauna in areas of Spartina spp. compared to uninvaded sites and suggested that the above-ground structure of the plant favours epifauna by providing habitat and larger surface for grazing (reviewed by Levin \& Talley 2000; also Bouma et al. 2009, Tang \& Kristensen 2010). The only epifaunal species we found enhanced in $S$. anglica habitat was the shore crab Paragrapsus laevis, perhaps because it finds protection or foraging space among the $S$. anglica culms.

\section{Comparison to other studies on Spartina anglica}

In light of conflicting studies reviewed in the 'Introduction' on the effects of Spartina spp. on macrofauna, particularly for $S$. anglica, we looked for trends in the results of our study and those of others on $S$. anglica (Table 7). We considered only published studies that sampled simultaneously in invaded and uninvaded habitats for comparison. Most of the papers only compared $S$. anglica infestations to unvegetated sediment. In these comparisons, indices for total macrofauna (species richness, diversity, 


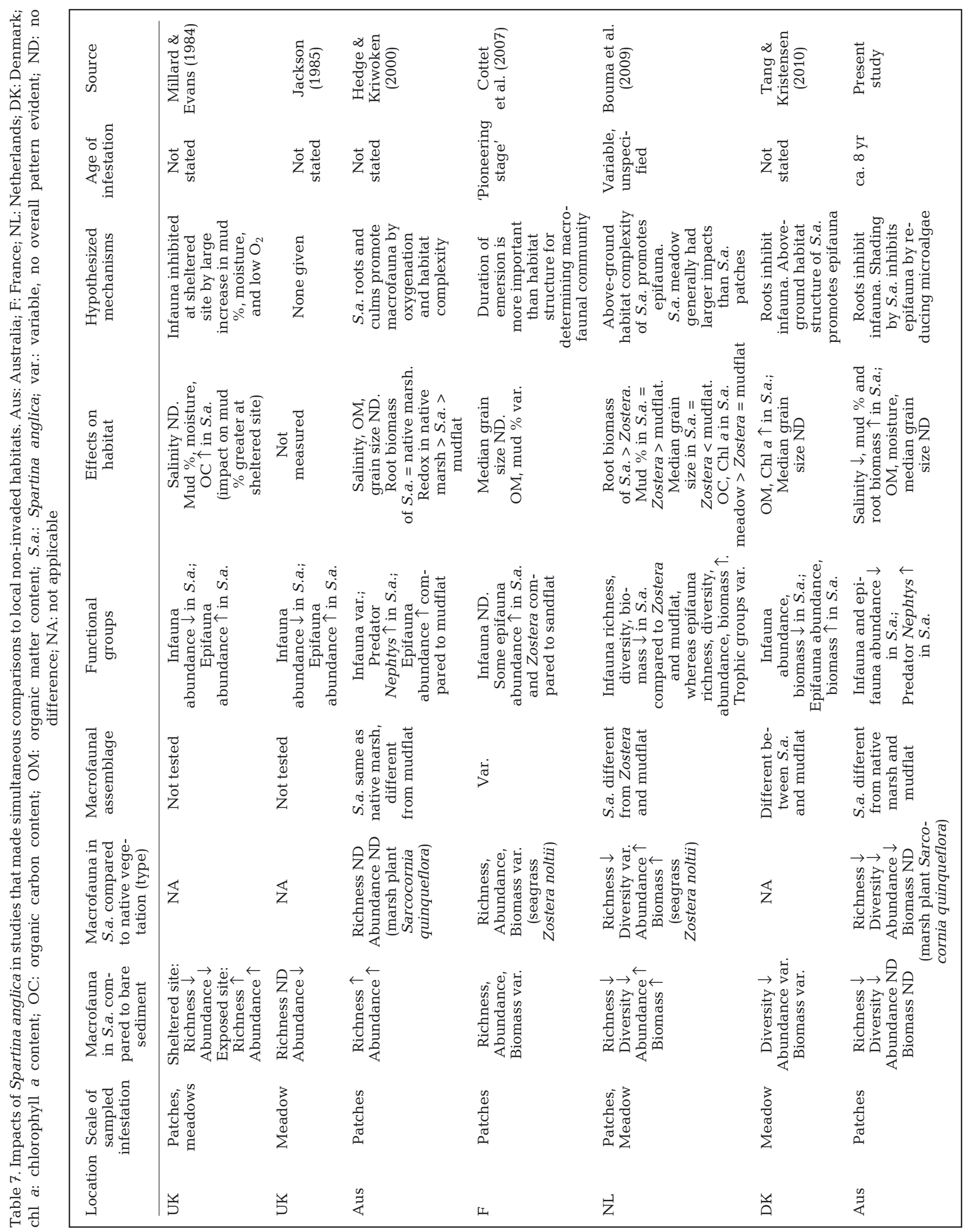


abundance, biomass) yielded highly variable results, from which it is difficult to generalize. For example, reduced values for some of these indices in S. anglica infestations were found by Jackson (1985), Bouma et al. (2009), Tang \& Kristensen (2010), and in the present study, whereas enhanced values were found by Hedge \& Kriwoken (2000) and Bouma et al. (2009). Some authors found highly variable results or a clear lack of difference for some indices (Jackson 1985, Cottet et al. 2007, Tang \& Kristensen 2010, present study), and Millard \& Evans (1984) found opposite results for sheltered and exposed sites.

Fewer studies compared macrofauna between Spartina anglica and native vegetation, and the findings are no clearer. Two studies made the comparison to seagrass habitat, finding some increases in abundance and biomass in $S$. anglica, some reduction of richness, and several highly variable results that revealed no clear pattern (Cottet et al. 2007, Bouma et al. 2009). Only Hedge \& Kriwoken (2000) and our study compared $S$. anglica to native saltmarsh (similar native marshes in Australia), yielding quite different results (discussed in more detail below).

These highly variable findings for total macrofauna indices reflect the impression in the literature for Spartina spp. as a whole, reviewed in the 'Introduction'. However, in papers that compared macrofaunal species assemblages using multivariate statistics, there were differences between $S$. anglica infestations and uninvaded habitats in all but one (Table 7), suggesting that a closer examination of results at the level of taxa or functional groups might reveal patterns. Indeed, a clearer picture of trends emerges when examining impacts of $S$. anglica on infauna and epifauna separately. Some of these papers did not distinguish between impacts on infauna and epifauna in their analyses, but we examined their species lists and drew the comparisons shown in Table 7.

In all studies including our own, infauna in Spartina anglica were either depleted or showed no clear difference compared to bare sediment or native vegetation (Table 7). In no case was the infauna promoted by the presence of $S$. anglica. Where authors have offered hypotheses to explain these findings, they include inhibition of infauna by below-ground plant structure, increased content of mud and moisture, and reduced oxygen. Some of the studies reported measurements of physical habitat parameters that corroborated these hypotheses (Table 7).

In contrast, epifauna in Spartina anglica showed enriched assemblages compared to bare sediment, and in one case compared to native vegetation (seagrass) (Table 7). The hypothesis to explain facilitation of epifauna was the aerial habitat complexity provided by $S$. anglica. The sole exception is our study, finding depleted epifauna in S. anglica. As discussed above, the reduced porewater salinity we measured in $S$. anglica patches can explain the depletion of epifauna by a shading effect on microalgal production. Consistent with this explanation is that in other studies in which epifauna were enhanced in S. anglica and porewater salinity was reported (Millard \& Evans 1984, Hedge \& Kriwoken 2000; Table 7), there were no differences in salinity among habitats (thus, no evidence for a shading effect). Also, in papers that reported chlorophyll a content in the surficial sediment, it was enhanced in $S$. anglica habitat along with the epifauna (Bouma et al. 2009, Tang \& Kristensen 2010; Table 7), again showing no evidence of a shading effect. From these comparisons we conclude that epifauna are generally facilitated by $S$. anglica unless there is a shading effect on microalgae that serve as an important food resource.

\section{Comparison to Spartina anglica elsewhere in Australia}

The contrasting findings between our study and Hedge \& Kriwoken's (2000) are important, particularly because they are from 2 temperate sites in Australia and the comparisons to native saltmarsh are similar in that the marshes are both dominated by Sarcocornia quinqueflora. Hedge \& Kriwoken (2000) found that total macrofaunal species richness and abundance were greater in $S$. anglica and native marsh than in mudflat. Furthermore, their multivariate analyses of assemblage structure revealed 2 groupings: one including the mudflat samples and the other combining both vegetated habitats. Essentially, Hedge \& Kriwoken's (2000) results from the state of Tasmania suggested that invasion of $S$. anglica into mudflat raises the invertebrate richness and abundance and converts the macrofaunal species assemblage into the equivalent of that in native saltmarsh. Our results in the neighbouring state of Victoria indicate a different and potentially more consequential impact, i.e. that invasion by $S$. anglica creates a unique macrofaunal assemblage, different from both mudflat and native saltmarsh, with reduced species richness, diversity, and abundance.

Possible reasons for the differing findings are apparent in Table 7. In comparing Spartina anglica patches to mudflat, we found indices for total macrofauna to decline, whereas Hedge \& Kriwoken (2000) found increases, but the discrepancy is mainly due to 
the epifauna. As explained above, our declines of epifauna were likely caused by a shading effect, whereas Hedge \& Kriwoken (2000) found no evidence for shading (no difference in porewater salinity). Furthermore, Hedge \& Kriwoken (2000) found no differences in modal grain size among habitats, whereas, although we found no differences in median grain size, we did find increased mud content in $S$. anglica patches. These comparisons of grain size measurements indicate that $S$. anglica at our site caused more of a shift to a depositional environment than it did at Hedge \& Kriwoken's (2000) site. Together, these observations of shading and depositional environment suggest that $S$. anglica at our site was denser and/or taller (i.e. more mature) than at Hedge \& Kriwoken's (2000) site. No measures of above-ground plant structure were given by Hedge $\&$ Kriwoken (2000), but the below-ground biomass in $S$. anglica patches at our site was ca. 4-fold greater than at their site, suggesting a corresponding difference in above-ground density. Such a difference in $S$. anglica canopy size between the 2 studies could account for the differences in shading and the impacts on epifauna. For example, Sullivan \& Currin (2000) investigated the relationship between Spartina spp. canopy size and shading, and found that microalgal production was lower underneath a tall form of $S$. alterniflora than under a short form. Therefore, whereas the epifauna at our site were likely inhibited by shading in the patches of relatively dense/tall S. anglica, the epifauna at Hedge \& Kriwoken's (2000) site may have merely benefitted from the aerial habitat provided by $S$. anglica that was less dense/tall.

In comparing Spartina anglica patches to native Sarcocornia quinqueflora marsh, we found indices for total macrofauna to decline, whereas Hedge \& Kriwoken (2000) found no differences (Table 7). Our declines were due to both epifauna and infauna, whereas Hedge \& Kriwoken's (2000) show no patterns for either group. The differing responses of epifauna can be explained along the same lines as the arguments above (reduced microalgal food resources at our site caused by shading from the larger Spartina anglica canopy), because Hedge \& Kriwoken (2000) found no differences in salinity or grain size between $S$. anglica patches and native marsh, whereas we did (Table 7). The fact that Hedge \& Kriwoken (2000) found epifauna to be facilitated by $S$. anglica compared to mudflat, but not compared to native marsh, may reflect that the epifauna benefitted from aerial structure of both plants ( $S$. anglica and Sarcocornia quinqueflora) equally compared to unvegetated sediment. Regarding infauna and their differing responses in the 2 studies, we found greater below-ground plant biomass in Spartina anglica patches compared to native marsh, whereas Hedge \& Kriwoken (2000) did not (Table 7). This suggests that burrowing in $S$. anglica sediment was inhibited relative to native marsh at our site, but not at Hedge \& Kriwoken's (2000) site.

Differing responses to invasion could also be related to differences in the resident macrofaunal assemblages in the uninvaded habitats. Only 4 of the 20 species we identified were also reported by Hedge \& Kriwoken (2000). Two of these species (Helograpsus haswellianus and Nephtys australiensis) responded similarly to invasion at both locations, showing some consistency between the studies, but the species that occurred at only one or the other location may simply have different inherent responses to invasion. In considering only the uninvaded habitats, Hedge \& Kriwoken (2000) found higher total macrofaunal species richness and higher abundance in the native saltmarsh compared to mudflat, whereas we found each of these measures to be equal between the 2 habitats. Perhaps this comparison reflects an important difference between the native marsh systems in the 2 locations that caused differing responses to invasion.

A caveat for comparing these studies is that each is based on samples collected in a single season. One might argue that comparing Victoria in autumn (present paper) to Tasmania in winter (Hedge \& Kriwoken 2000) is not appropriate, but the separation is only $3 \mathrm{mo}$, and it is unlikely that these 2 considerably different systems normally converge to the same characteristics during the same season. Indeed, Cottet et al. (2007) found high seasonal stability of the macrofaunal community in habitats invaded by Spartina anglica.

\section{Predictable impacts of Spartina anglica}

Based on our results and literature analysis (Table 7), we present 2 general predictions about the impacts of $S$. anglica on macrofauna. (1) When sufficiently dense, the below-ground biomass of $S$. anglica excludes infauna due to dense roots/rhizomes and sediment compaction (van Wesenbeeck et al. 2007, Bouma et al. 2009, present study), whereas below some threshold density there is no impact (cf. Hedge \& Kriwoken 2000). The impact relative to a habitat of native vegetation depends on the relative abundance of below-ground biomass in the 2 habitats. (2) The aerial portion of $S$. anglica promotes epi- 
fauna by providing habitat complexity and possibly protection (most references in Table 7), except when the plant is so dense that it reduces microalgal productivity due to shading (present study). The impact relative to native vegetation again depends on the relative densities of the plants, and perhaps their above-ground architectures. Finally, because of the differing predicted impacts on infauna and epifauna, the overall impact of $S$. anglica on the total macrofaunal assemblage is not possible to predict (see the highly variable findings in Table 7).

Note that the density of Spartina anglica infestation is a critical factor in both of our predictions. Density is often related to age of infestation, and other authors have emphasized the importance of invasion age or maturity for the impacts of various Spartina spp. (Levin \& Talley 2000, Neira et al. 2005, 2007, Bouma et al. 2009).

Two other factors that might have predictive value are the areal extent of an invasion and the hydrodynamic regime. We included these factors in Table 7 when information was available, but such details are rarely published. Bouma et al. (2009) found that meadows of Spartina anglica generally had greater impacts than small patches, presumably because of less influence from edge effects. Also, effects of aerial plant architecture on hydrodynamics and sediment deposition are unlikely to be fully developed in a small patch (Bouma et al. 2005, Neira et al. 2006, Peralta et al. 2008). Therefore, some of the variability in findings among other studies in Table 7 might be due to their being done mostly on small patches of $S$. anglica. Furthermore, the impacts of $S$. anglica at our site might have been stronger if the plants had developed into a large meadow rather than being small patches. Exposure to currents and waves can also have further complex effects. Hydrodynamic regime proved an important factor in the results of Millard \& Evans (1984), with the overall impacts of $S$. anglica on total macrofauna indices being opposite at exposed and sheltered sites. Also, Swales et al. (2004) showed that growth and sediment-trapping effects of $S$. anglica are influenced by local wave energy. We recommend that future studies report information on age and areal extent of infestations, density of above- and below-ground biomass, and hydrodynamic regime.

\section{Implications for food webs}

The reduced richness, diversity, and abundance of macrofauna in areas invaded by Spartina anglica in
Anderson Inlet may result in less diversity and biomass of higher trophic levels and reduced food resources for coastal birds and fishes. These degenerative impacts on the coastal ecosystem are of particular concern where $S$. anglica has invaded wetlands of international importance (e.g. those recognized by the Ramsar Convention), such as ones in southeastern Australia that are habitat for rare and endangered species, including the eastern curlew, eastern great egret, and royal spoonbill. These birds feed on crustaceans in Anderson Inlet during nesting and migration (Blood 1995). Colonization of mudflat by $S$. anglica reduces not only the density of prey but also the extent of foraging ground for these birds. Furthermore, the biomass of $S$. anglica does not necessarily enter the food web. Stable-isotope studies of macrofaunal communities in San Francisco Bay and neighbouring estuaries showed that the native and hybrid Spartina spp. do not contribute significantly to the nutrition of surface-feeding molluscs and crustaceans (Brusati \& Grosholz 2009). Stable-isotope studies in Anderson Inlet also indicated that $S$. anglica does not contribute significantly to the nutrition of benthic crustacean detritivores (Hindell 2008), although it was found to be a major nutritional contributor to estuary perch Macquaria colonorum (Hindell \& Warry 2010).

Acknowledgements. We are grateful to L. Leunig and S. Howe (Parks Victoria) for field and data support, B. Kefford for statistical advice, the Museum Victoria for confirming the identifications of some species, and S. Kaserzon, S. Bombaci, C. Grandison, I. Cutajar, and J. O'Brien for field assistance. J. Cutajar thanks the Environmental Science staff at RMIT University for assistance, especially J. Hughes and S. Holden. The manuscript was improved with comments from 4 anonymous reviewers.

\section{LITERATURE CITED}

Adam P (2002) Saltmarshes in a time of change. Environ Conserv 29:39-61

Bertness MD (1984) Ribbed mussels and Spartina alterniflora production in a New England saltmarsh. Ecology 65:1794-1807

Blood K (1995) Spartina in Anderson Inlet, Victoria. In: Rash J, Williamson R, Taylor S (eds) Proceedings of the Australasian conference on Spartina control. Victorian Government Publication, Melbourne

Boon PI, Allen T, Brook J, Carr G and others (2011) Mangroves and coastal saltmarsh of Victoria: distribution, condition, threats and management. Institute for Sustainability and Innovation, Victoria University, Melbourne

Boston KG (1981) The introduction of Spartina townsendii to Australia. In: Occasional papers, Vol 6. Melbourne State College, Melbourne, p 1-57

Bouma TJ, De Vries MB, Low E, Peralta G, Tanczos IC, Van de Koppel J, Herman PMJ (2005) Trade-offs related to 
ecosystem-engineering: a case study on stiffness of emerging macrophytes. Ecology 86:2187-2199

> Bouma TJ, Ortells V, Ysebaert T (2009) Comparing biodiversity effects among ecosystem engineers of contrasting strength: macrofauna diversity in Zostera noltii and Spartina anglica vegetations. Helgol Mar Res 63:3-18

- Brenchley GA (1982) Mechanisms of spatial competition in marine soft-bottom communities. J Exp Mar Biol Ecol 60: 17-33

Bridgewater PB (1975) Peripheral vegetation of Westernport Bay. Proc R Soc Vic 87:69-78

> Brusati ED, Grosholz ED (2006) Native and introduced ecosystem engineers produce contrasting effects on estuarine infaunal communities. Biol Invasions 8:683-695

> Brusati ED, Grosholz ED (2009) Does invasion of hybrid cordgrass change estuarine food webs? Biol Invasions 11: 917-926

> Capehart AA, Hackney CT (1989) The potential role of roots and rhizomes in structuring saltmarsh benthic communities. Estuaries 12:119-122

> Chen Z, Guo L, Jin B, Wu J, Zheng G (2009) Effects of the exotic plant Spartina alterniflora on macrobenthos communities in salt marshes of the Yangtze River Estuary, China. Estuar Coast Shelf Sci 82:265-272

Chung CH (1983) Geographical distribution of Spartina anglica in China. Bull Mar Sci 33:753-758

Chung CH (1990) Twenty five years of introduced Spartina anglica in China. In: Gray A, Benham P (eds) Spartina anglica: a research review. Publication No. 2, Institute of Terrestrial Ecology Research, London

> Cottet M, De Montaudouin X, Blanchet H, Lebleu P (2007) Spartina anglica, eradication experiment and in situ monitoring assess structuring strength of habitat complexity on marine macrofauna at high tidal level. Estuar Coast Shelf Sci 71:629-640

da Cunha Lana P, Guiss C (1991) Influence of Spartina alterniflora on structure and temporal variability of macrobenthic associations in a tidal flat of Paranagua Bay (south-eastern Brazil). Mar Ecol Prog Ser 73:231-244

da Cunha Lana P, Guiss C (1992) Macrofauna-plantbiomass interactions in a euhaline salt marsh in Paranaguá Bay (SE Brazil). Mar Ecol Prog Ser 80:57-64

> Dethier MN, Hacker SD (2005) Physical factors vs. biotic resistance in controlling the invasion of an estuarine marsh grass. Ecol Appl 15:1273-1283

Edgar GJ, Shaw C (1993) Inter-relationships between sediments, seagrasses, benthic invertebrates and fishes in shallow marine habitats of south-western Australia. In: Walker D, Wells F, Kirkman H, Lethbridge R (eds) Marine flora and fauna of Rottnest Island, Western Australia. Western Australian Museum, Perth

Frid C, James R (1989) The marine invertebrate fauna of a British coastal salt marsh. Holarct Ecol 12:9-15

Gribsholt B, Kristensen E (2002) Effects of bioturbation and plant roots on salt marsh biogeochemistry: a mesocosm study. Mar Ecol Prog Ser 241:71-87

Groenendijk AM (1986) Establishment of Spartina anglica population on a tidal mudflat: a field experiment. J Environ Manage 22:1-12

$>$ Hacker SD, Dethier MN (2006) Community modification by a grass invader has differing impacts for marine habitats. Oikos 113:279-286

> Hedge P, Kriwoken LK (2000) Evidence for effects of Spartina anglica invasion on benthic macrofauna in Little Swanport estuary, Tasmania. Austral Ecol 25:150-159
Hindell JS (2008) Base for nutritional support of estuary perch in Anderson Inlet: evaluating the relative importance of Spartina. Arthur Rylah Institute for Environmental Research Technical Report Series No. 2008/60, Dept. of Sustainability and Environment, Victoria

Hindell JS, Warry FY (2010) Nutritional support of estuary perch (Macquaria colonorum) in a temperate Australian inlet: evaluating the relative importance of Spartina. Estuar Coast Shelf Sci 90:159-167

Hobbs RJ (2000) Land-use changes and invasions. In: Mooney H, Hobbs R (eds) Invasive species in a changing world. Island Press, Washington, DC

Jackson D (1985) Invertebrate populations associated with Spartina anglica saltmarsh and adjacent intertidal mudflats. Estuarine Brackishwater Sci 40:8-14

Jackson D, Mason CF, Long SP (1985) Macroinvertebrate populations and production on a salt marsh in east England dominated by Spartina anglica. Oecologia 65: 406-411

> Kriwoken LK, Hedge P (2000) Exotic species and estuaries: managing Spartina anglica in Tasmania, Australia. Ocean Coast Manag 43:573-584

> Lee WG, Partridge TR (1983) Rates of spread of Spartina anglica and sediment accretion in the New River estuary, Invercargill, New Zealand. NZ J Bot 21:231-236

Levin LA, Talley TS (2000) Influences of vegetation and abiotic environmental factors on salt marsh invertebrates. In: Weinstein MP, Kreeger DA (eds) Concepts and controversies in tidal marsh ecology. Kluwer, Dordrecht

> Levin LA, Neira C, Grosholz ED (2006) Invasive cordgrass modifies wetland trophic functions. Ecology 87 : 419-432

> Lotze HK, Lenihan HS, Bourque BJ, Bradbury RH and others (2006) Depletion, degradation, and recovery potential of estuaries and coastal seas. Science 312:1806-1809

Lowe S, Browne M, Boudjelas S, De Poorter M (2000) 100 of the world's worst invasive alien species. IUCN, Auckland

Millard AV, Evans PR (1984) Colonization of mudflats by Spartina anglica; some effects on invertebrate and shorebird populations at Lindisfarne. In: Doody JP (ed) Spartina anglica in Great Britain. Nature Conservancy Council, Cambridgeshire

> Mudd SM, D'Alpaos A, Morris JT (2010) How does vegetation affect sedimentation on tidal marshes? Investigating particle capture and hydrodynamic controls on biologically mediated sedimentation. J Geophys Res 115: F03029 doi:10.1029/2009JF001566

- Nehring S, Hesse KJ (2008) Invasive alien plants in marine protected areas: the Spartina anglica affair in the European Wadden Sea. Biol Invasions 10:937-950

> Neira C, Levin LA, Grosholz ED (2005) Benthic macrofaunal communities of three sites in San Francisco Bay invaded by hybrid Spartina, with comparison to uninvaded habitats. Mar Ecol Prog Ser 292:111-126

Neira C, Grosholz ED, Levin LA, Blake R (2006) Mechanisms generating modification of benthos following tidal flat invasion by a Spartina hybrid. Ecol Appl 16: 1391-1404

Neira C, Levin LA, Grosholz ED, Mendoza G (2007) Influence of invasive Spartina growth stages on associated macrofaunal communities. Biol Invasions 9:975-993

Neves JP, Simoes MP, Ferreira LF, Medeira M, Gazarini LC (2010) Comparison of biomass and nutrient dynamics between an invasive and native species in a Mediterranean saltmarsh. Wetlands 30:817-826 
Peralta G, van Duren LA, Morris EP, Bouma TJ (2008) Consequences of shoot density and stiffness for ecosystem engineering by benthic macrophytes in flow dominated areas: a hydrodynamic flume study. Mar Ecol Prog Ser 368:103-115

Pielou EC (1966) The measurement of diversity in different types of biological collections. J Theor Biol 13:131-144

Poore GCB (2007) Crabs, hermit crabs and allies. Museum Victoria, Melbourne

Ranwell DS (1964) Spartina saltmarshes in southern England. Rate and seasonal pattern of sediment accretion. J Ecol 52:79-94

Ringold P (1979) Burrowing, root mat density, and the distribution of the fiddler crabs in eastern United States. J Exp Mar Biol Ecol 36:11-21

Rönnbäck P, Kautsky N, Pihl L, Troell M, Soerqvist T, Wennhage $H$ (2007) Ecosystem goods and services from Swedish coastal habitats: identification, valuation, and implications of ecosystem shifts. Ambio 36:534-544

Saintilan N (2009) Australian saltmarsh ecology. CSIRO Publishing, Collingwood

Simpson J (1996) Wading birds of Anderson Inlet. In: Rash J, Taylor J, Williamson S (eds) Proceedings of the Australasian conference on Spartina control. Victorian Government Publication, Melbourne

Sullivan MJ, Currin CA (2000) Community structure and functional dynamics of benthic microalgae in salt marshes. In: Weinstein MP, Kreeger DA (eds) Concepts and controversies in tidal marsh ecology. Kluwer, Dordrecht

Swales A, MacDonald IT, Green MO (2004) Influence of

Editorial responsibility: Omar Defeo,

Montevideo, Uruguay wave and sediment dynamics on cordgrass (Spartina anglica) growth and sediment accumulation on an exposed intertidal flat. Estuaries 27:225-243

- Tang M, Kristensen E (2010) Associations between macrobenthos and invasive cordgrass, Spartina anglica, in the Danish Wadden Sea. Helgol Mar Res 64:321-329

> Thompson JD (1991) The biology of an invasive plant. What makes Spartina anglica so successful? Bioscience 41: 393-401

> van Wesenbeeck BK, van de Koppel J, Herman PMJ, Bakker JP, Bouma TJ (2007) Biomechanical warfare in ecology; negative interactions between species by habitat modification. Oikos 116:742-750

Wang RZ, Yuam L, Zhang LQ (2010) Impacts of Spartina alterniflora invasion on the benthic communities of saltmarshes in the Yangtze estuary China. Ecol Eng 36: 799-806

Weiss JER, Iaconis LJ (2002) Pest plant invasiveness assessment. DNRE Victoria, Melbourne

Wells A (1995) Rice grass in Tasmania - an overview. In: Rash J, Taylor J, Williamson S (eds) Proceedings of the Australasian conference on Spartina control. Victorian Government Publication, Melbourne

Whitlatch RB (1981) Animal-sediment relationships in intertidal marine benthic habitats: some determinants of deposit feeding diversity. J Exp Mar Biol Ecol 53: $31-45$

> Zhou HX, Liu JE, Qin P (2009) Impact of an alien species (Spartina alterniflora) on the macrobenthos community of Jiansu coastal intertidal ecosystem. Ecol Eng 35: $521-528$

Submitted: December 30, 2010; Accepted: May 14, 2012 Proofs received from author(s): August 30, 2012 